\title{
Oro över coronapandemin i det svenska samhället
}

\begin{abstract}
Worry about the coronavirus pandemic in Sweden
The purpose of this study is to provide insight into individuals' degree of worrying about the corona pandemic in Sweden. Using survey data $(n=3,040)$, we study: 1) how widespread worrying about the corona pandemic is; 2 ) what aspects of the pandemic people worry about; 3 ) differences in the level of worrying among demographic and socio-economic groups; 4) the extent to which worries are related to factors such as personality, religiosity, political orientation, trust, and risk perceptions; and 5) consequences of worrying for social contacts and quality of life, as well as for behaviours and opinions in relation to government recommendations. Results show that worrying about the coronavirus pandemic in Sweden is widespread and primarily about one's own or relatives' health. Moreover, we find evidence of group differences, where elderly, women, and those with lower incomes articulate higher levels of worry. Several explanatory factors are linked to worrying about the pandemic. In particular, risk perceptions explain a large share of variation between individuals and groups. While those who worry more report greater compliance with authorities' recommendations and reduced social activities, they also report a lower quality of life during the pandemic.
\end{abstract}

Keywords: worry, corona pandemic, attitudes, behavior, Sweden

CORONAPANDEMIN OCH SPRIDNINGEN av viruset SARS-CoV-2 har haft en stor inverkan på det svenska samhället. I slutet av januari 2021 hade över 11000 människor i Sverige avlidit i covid-19 (Fohm 2021). Under våren 2020 såg Sverige den största kvartalsnedgången i BNP på fyra decennier (SCB 2020) och i slutet av 2020 hade över 116000 människor blivit varslade sedan i mars (Ekonomifakta 2020). Dessutom har samhällets åtgärder för att minska smittspridningen (till exempel rekommendationer om social distansering) haft stora konsekvenser för människors sociala tillvaro. Även om Sverige haft en mjukare linje än många andra länder när det gäller samhällets åtgärder för att minska smittspridningen har coronapandemin tveklöst inneburit stora omställningar, begränsningar och påfrestningar i människors vardag.

Mot bakgrund av detta kan vi förvänta oss att många människor upplever en betydande oro över coronapandemin. Inte minst borde många människor uppleva oro 
över att de själva eller deras anhöriga kan smittas och i värsta fall avlida. Vidare har sannolikt även social isolering, tidspress på grund av distansarbete och hemmavarande barn, permitteringar, uppsägningar och inkomstbortfall gett upphov till en ökad oro hos många. Samtidigt som vi kan förvänta oss en generellt högre grad av oro i samhället så har olika grupper förmodligen drabbats i olika stor utsträckning. Framför allt kan man förvänta sig att demografiska grupper som löper en större risk att drabbas allvarligt av viruset, samt människor i mer socioekonomiskt utsatta positioner, upplever en särskilt hög grad av oro över coronapandemin.

Medan ett flertal studier har undersökt hur olika grupper drabbats ekonomiskt under coronapandemin (se t.ex. Brodeur, Gray, Islam m.fl. 2020) fokuserar vi i denna studie på gruppskillnader, och därmed ojämlikhet, i de subjektiva upplevelserna av oro kopplade till pandemin. Att undersöka hur olika grupper drabbas i termer av upplevd oro är viktigt, inte minst då oro har visat sig vara förknippat med många negativa utfall associerade med en sämre livskvalitet, till exempel försämrad fysisk hälsa, ångest och depression (Brosschot, Gerin \& Thayer 2006; Watkins 2008; Kertz, Bigda-Peyton, Rosmarin m.fl. 2012). Då coronaviruset visat sig vara särskilt farligt för äldre, men även för vissa andra grupper i befolkningen (Jordan, Adab \& Cheng 2020), är det angeläget att öka förståelsen för om och hur oro över pandemin varierar mellan olika grupper i samhället, inte minst ur jämlikhets- och rättviseperspektiv (jfr Graham 2020). Men att fokusera på oron över pandemin är även viktigt då den i hög grad kan tänkas påverka människors beteenden och åsikter, till exempel i vilken utsträckning de följer myndigheternas rekommendationer eller efterfrågar kraftigare åtgärder för att minska smittspridningen. I detta avseende kan man tänka sig att oron över coronapandemin även kan ha positiva konsekvenser, åtminstone i den utsträckning oron leder till ett mer ansvarsfullt beteende när det gäller social distansering och att i övrigt följa myndigheternas rekommendationer.

För att öka kunskapen om människors oro över coronapandemin i Sverige använder vi ett enkätdatamaterial ( $\mathrm{n}=3$ 040) från Ipsos svenska webbpanel i vilken vi ställt en rad frågor om människors oro över pandemin, såsom hur stor denna oro är samt vad den mer konkret består i. Vidare studerar vi i vilken utsträckning oro över coronapandemin varierar såväl mellan olika demografiska och socioekonomiska grupper i samhället som mellan individer som skiljer sig åt med avseende på en rad olika faktorer som till exempel livsåskådning, tillit och riskuppfattningar. Slutligen undersöker vi även några av orons tänkbara konsekvenser, till exempel för människors sociala kontakter och livskvalitet, samt hur de genom sina beteenden och åsikter förhåller sig till myndigheternas åtgärder för att minska smittspridningen. 


\section{Tidigare forskning}

\section{Oro över coronapandemin}

Oro kan förstås som återkommande tankar om framtida scenarier och händelser med potentiellt negativa konsekvenser (Borkovec 1994). Denna oro kan ackompanjeras av känslor av obehag eller ångest, i synnerhet om objektet för oron rör individens eget liv eller personer som står henne nära (Boehnke, Schwartz, Stromberg m.fl. 1998). Vidare kan en distinktion göras utifrån om oron är av mer generell karaktär eller avser specifika och avgränsade företeelser eller områden. Den förstnämnda mäts ofta med olika skalor - till exempel i Penn State Worry Questionnaire (se t.ex. Fresco, Heimberg, Mennin m.fl. 2002) - som innehåller frågor som "hur orolig har du känt dig den senaste tiden?”. Den områdesspecifika oron är däremot kopplad till avgränsade företeelser, såsom att få cancer, att förlora sitt arbete eller, som i detta fall, coronapandemin.

Oro kan även delas in i mikro- respektive makro-oro beroende på objektet för oron (Boehnke, Schwartz, Stromberg m.fl. 1998). Mikro-oro rör sådant som ligger nära individen själv, till exempel den egna hälsan, arbetssituationen eller anhörigas välbefinnande. Makro-oro rör sådant som återfinns i samhället utanför individens egen sfär, till exempel den svenska ekonomin, klimatförändringarna eller hot mot demokratin. Det är rimligt att anta att coronapandemin ger upphov till oro på både mikro- och makronivå, eftersom människor kan oroa sig över att de själva eller deras anhöriga kan bli smittade eller förlora arbetet samtidigt som de oroar sig över hur den svenska ekonomin påverkas av pandemin eller hur många människor som kommer att avlida till följd av covid-19. I en brittisk studie om konsekvenserna av coronapandemin drog författarna slutsatsen att människor främst uttryckte mikro-oro, det vill säga att de främst oroade sig för sin familj och sin egen ekonomiska situation (Kleinberg, van der Vegt \& Mozes 2020). Vidare fann Barzilay med flera (2020) att människor tenderade att vara mer oroade över närståendes hälsa än över den egna ekonomin, vilket tyder på att hot mot hälsan utgör en större källa till oro än ekonomiska problem till följd av pandemin.

Givet de risker som är knutna till såväl hälsa som ekonomi, både för den enskilda individen och för andra människor samt samhället i stort, är det lätt att förstå att människor är oroade över coronapandemin. Ett flertal studier från andra länder pekar här på att coronapandemin haft negativa konsekvenser för oro i, till exempel, Kina och Storbritannien (Kleinberg, van der Vegt \& Mozes 2020; Huang \& Zhao 2020). I en indisk studie framgår det att $72 \%$ oroade sig för sig själva och sina närstående i relation till spridningen av covid-19 (Roy, Tripathy, Kumar Kar m.fl. 2020). En studie genomförd i Tyskland visar på stora ökningar av såväl depressionssymtom (från 5,6 \% till 14,3 \%) som oro (från $39 \%$ till 65,2 \%) under coronapandemin (Bäuerle, Teufel, Musche m.fl. 2020). Utifrån icke-representativa data från Cypern fann Solomou och Constantinidou (2020) att $41 \%$ av respondenterna uppvisade mild ångest till följd av coronapandemin. Författarna fann att ökningen var substantiell i jämförelse med tidigare studier innan pandemin då bland annat $23 \%$ av de svarande uppgav lindriga 
eller allvarliga ångestsymtom i jämförelse med cirka $1 \%$ innan pandemin. Ingen av dessa studier ger dock svaret på den direkta orsaken (smittspridning, politiska åtgärder etcetera) till de förhöjda nivåerna av oro och liknande fenomen. De visar bara att populationsmedelvärdena sannolikt ökade i och med pandemin. I en metastudie av psykisk hälsa under coronapandemin kommer Salari med flera (2020) fram till att nästan 30 \% upplever ångest. Siffrorna i dessa studier är dock inte jämförbara i strikt bemärkelse, beroende på skillnader i mätmetoder, tidpunkt och populationer, men de visar trots allt att oro på grund av coronapandemin är relativt utbredd samt att många människor verkar oroa sig mer under pandemin än innan.

\section{Gruppskillnader i oro över coronapandemin}

Hög ålder har identifierats som en särskilt betydelsefull riskfaktor för att bli svårt sjuk eller avlida i covid-19 (Jordan, Adab, Cheng m.fl. 2020) och ett antal studier har också visat på en särskilt hög grad av oro över coronapandemin bland äldre. Till exempel har ett antal svenska studier visat att äldre upplevt ökad stress, ångest och oro under pandemin (se t.ex. Gustavsson \& Beckman 2020; Kivi, Hansson \& Bjälkebring 2020). Det framgår dock inte av dessa studier huruvida äldre har upplevt en större oro än andra åldersgrupper. I en kinesisk studie fann dock Huang och Zhao (2020) att äldre oroade sig mer än yngre över coronapandemin. Samtidigt fann Mann med flera (2020), i en studie från USA, att oron över ekonomin under coronapandemin generellt var större bland yngre individer. Detta är inte förvånande, då yngre (jämfört med äldre) löper en större risk att drabbas ekonomiskt snarare än hälsomässigt av coronapandemin. Det är dock värt att notera att studier om generell oro visar att oron minskar ju äldre människor blir (se t.ex. Basevitz, Pushkar, Chaikelson m.fl. 2008), vilket understryker vikten av att ta personlighetsdrag kopplade till generell oro (vilket är en del av personlighetsdraget neuroticism) i beaktande när man undersöker åldersskillnaders betydelse för områdesspecifik oro såsom oro över coronapandemin.

Samtidigt som hög ålder utgör en av de främsta riskfaktorerna när det gäller dödlighet och allvarlig sjukdom till följd av covid-19 så antyder den tillgängliga forskningen att en rad andra demografiska och socioekonomiska faktorer som kön och inkomst också kan ha stor betydelse, då män och ekonomiskt utsatta grupper har drabbats hårdare (se t.ex. Patel, Nielsen, Badiani m.fl. 2020; Williamson, Walker, Bhaskaran m.fl. 2020). Forskningen visar även på skillnader i oro över coronapandemin, till exempel mellan män och kvinnor (van der Vegt \& Kleinberg 2020). Trots att män relativt sett löper en högre risk att bli allvarligt sjuka eller avlida i covid-19 oroar de sig mindre än kvinnor. Detta skulle kunna förklaras av könsskillnader i de kognitiva och känslomässiga reaktionerna på coronapandemin, då män tenderar att oroa sig mer för de ekonomiska och samhälleliga konsekvenserna (makro-oro) medan kvinnor i större utsträckning oroar sig för hälsa och familj (mikro-oro) (van der Vegt \& Kleinberg 2020). Eftersom problem som rör hälsa och familj generellt leder till en högre grad av oro än problem som rör ekonomin och samhället är dessa könsskillnader inte särskilt förvånande. Samtidigt vet vi också att män i allmänhet är mer benägna att acceptera större risker än kvinnor (se t.ex. Kahan, Braman, Gastil m.fl. 2007), vilket indikerar 
att upplevelser av risk (riskuppfattningar) inte alltid återspeglar faktiska risker. När man studerar oro är det därför viktigt att utöver demografiska och socioekonomiska faktorer även ta riskuppfattningar i beaktning.

Douglas (1966) hävdar att riskuppfattningar varierar mellan olika samhällen och kulturer likväl som mellan individer och grupper inom samhällen (se även Douglas \& Wildavsky 1982). Även om Douglas teori har kritiserats så pekar även dess kritiker (se t.ex. Wilkinson 2001) på att människors erfarenheter påverkar hur deras riskuppfattningar struktureras. Dryhurst med flera (2020) visar i sin komparativa studie av riskuppfattningar kopplade till coronapandemin att dessa visserligen varierar mellan länder, men att skillnaderna inte är så stora. Dock finns relativt stora skillnader mellan olika grupper inom samhällen. Det är värt att notera att Dryhurst med flera (2020) använder sig av ett alltmer välanvänt index (COVID-19 Risk Perception) som kombinerar mått på hur farligt man tror att viruset är samt bedömningar av hur stor sannolikheten är att man kommer drabbas med mått på hur oroad man är över coronaviruset. Utifrån denna studie (och andra som använder liknande mått) är det alltså inte möjligt att uttala sig om relationen mellan riskuppfattningar och oro över coronapandemin. Detta är olyckligt, då oro inte nödvändigtvis återspeglar upplevda risker och att riskuppfattningar och oro därmed inte alltid hänger ihop (Sjöberg 1998). Vidare finner man ofta att sambandet mellan riskuppfattningar och oro är starkare ju allvarligare risken bedöms vara (Shiloh, Wade, Roberts m.fl. 2013). Följaktligen finns det goda skäl att göra en distinktion mellan riskuppfattningar och oro samt att undersöka om oro över coronapandemin varierar både mellan olika samhällsgrupper samt mellan individer med olika riskuppfattningar.

Utöver individers grupptillhörigheter och deras subjektiva upplevelser av risker är det rimligt att förvänta sig att människors oro över coronapandemin delvis beror på deras tillit till sina medmänniskor samt till de politiska ledare och de institutioner som har ansvar för samhällets hantering av pandemin. Tidigare studier visar att oron över coronapandemin i allmänhet är större i länder där förtroendet för regeringen är förhållandevis lågt (Sabat, Neuman-Böhme, Varghese m.fl. 2020) och att mindre tillit till andra människor (till exempel att man inte litar på att de följer myndigheternas rekommendationer) är förknippat med en högre grad av oro över pandemin (Jovančević \& Milićević 2020). Vidare har människors livsåskådning kopplats till oro och liknande fenomen. Till exempel har religiositet visat sig fungera som en buffert mot svåra livsvillkor (Hastings \& Roeser 2020), vilket skulle kunna tyda på att religiösa individer upplever en jämförelsevis lägre grad av oro över pandemin. Nyligen publicerade studier har även visat att politisk ideologi kan påverka det upplevda hotet från coronapandemin. De flesta studier har dock genomförts i en amerikansk kontext, där konservatism har kopplats till en mindre grad av upplevt hot från coronapandemin (se t.ex. Calvillo, Ross, Garcia m.fl. 2020). Det är dock osäkert i vilken utsträckning man kan förvänta sig liknande resultat i en svensk kontext. 


\section{Konsekvenser av oro över coronapandemin}

Utöver de negativa effekterna av oro på den fysiska och psykiska hälsan har oro även visat sig ha betydelse för individers upplevda livskvalitet i termer av generell livstillfredsställelse, då människor som ofta är oroliga även tenderar att vara mindre tillfredsställda med livet i sin helhet (Paolini, Yanez \& Kelly 2006; Ng, Diener, Aurora m.fl. 2009; Fors \& Brülde 2011). Dessa resultat antyder att oro över coronapandemin skulle kunna påverka människors livstillfredsställelse negativt. Medan oro kan få allvarliga konsekvenser för den enskilde individen kan den också få betydande konsekvenser för samhället i stort eftersom ökad fysisk och psykisk ohälsa innebär stora samhällskostnader i form av förlorade arbetsinsatser och en ökad ekonomisk belastning för sjukvården. I relation till coronapandemin har det även visat sig att oro över pandemin kan ha direkta negativa konsekvenser för samhället. Till exempel har Brück med flera (2020) visat på ett samband mellan coronarelaterad oro och en lägre grad av social och institutionell tillit.

Även om forskningen om oro primärt fokuserat på dess negativa konsekvenser visar den också på positiva följder. Oro kan exempelvis fungera som en motiverande faktor som driver individen att åtgärda och mildra uppkomna problem (t.ex. Davey 1994; Watkins 2008; Sweeny \& Dooley 2017). På detta sätt kan oron bidra till att individer försöker öka kontrollen över en problematisk situation för att förhindra negativa händelseförlopp eller minimera konsekvenserna av dessa (Freeston, Rhéaume, Letarte m.fl. 1994). Till exempel har oro för cancer visat sig vara kopplad till en större benägenhet att genomgå cancerscreening (Moser, Mccaul, Peters m.fl. 2007) och på ett liknande sätt är oro för influensa förknippad med en större benägenhet att vaccinera sig (Chapman \& Coups 2006). Vidare visar Hacker med flera (2013) att ekonomisk oro är relaterad till positiva attityder gällande statliga åtgärder som syftar till att reducera ekonomisk osäkerhet. I förhållande till coronapandemin kan oron därmed tänkas leda till mindre risktagande samt en större benägenhet att stödja och följa myndigheternas rekommendationer.

\section{Data och metod}

Datamaterialet som används i denna studie kommer från en enkät om svenskarnas upplevelser, åsikter och beteenden med avseende på coronapandemin. Datainsamlingen genomfördes under juni 2020 av Ipsos på uppdrag av Sociologiska institutionen vid Umeå universitet. Datamaterialet baseras på svaren från 3040 individer mellan 18 och 74 år som ingår i en webb-baserad panel (vid tidpunkten för datainsamlingen fanns 52211 individer i panelen). Datainsamlingen genomfördes för att uppnå en så god representativitet som möjligt med avseende på den vuxna befolkningen i Sverige. En jämförelse mellan urvalet som används i denna studie och befolkningsstatistik från Statistiska Centralbyrån (SCB) visar på en hög representativitet vad gäller kön, ålder och region.

Flertalet av enkätfrågorna besvarades med hjälp av två typer av svarsskalor; en elvagradig skala och en femgradig så kallad Likertskala. Graden av oro över coronapan- 
demin mättes på en elvagradig skala där extremvärdena specificerades med etiketterna "inte alls oroad" (0) och "extremt oroad" (10). Till skillnad från den generella oro som ofta mäts med hjälp av mer omfattande mätinstrument och skalor, till exempel Penn State Worry Questionnaire, mäter vi oro kopplad till ett specifikt område, det vill säga coronapandemin. Men då det även visats att generell oro kan mätas med enstaka enkätfrågor (Schroder, Clark \& Moser 2019) har vi valt denna strategi för att mäta oro över coronapandemin. Vi har även använt denna typ av elvagradig svarsskala för övriga mått i studien som avser gradskillnader, till exempel i politisk och mellanmänsklig tillit, religiositet eller politisk-ideologiska uppfattningar.

För att mäta åsikter om och ställningstaganden till olika påståenden, till exempel huruvida "myndigheterna i Sverige borde införa mer strikta åtgärder för att minska smittspridningen", använde vi en femgradig Likertskala. De två lägsta värdena på denna skala indikerar att man tar avstånd från påståendet (1="tar starkt avstånd" och $2=$ "tar avstånd"), de två högsta att man instämmer i det (4="instämmer" och 5="instämmer starkt") och mittalternativet (3) att man varken instämmer eller tar avstånd. Ett antal andra frågor hade unika svarsalternativ, exempelvis frågor som rör hur ofta man ägnat sig åt olika vardagliga beteenden eller aktiviteter under pandemin ("mindre ofta", "lika ofta", "oftare"). Frågeformuleringarna för de variabler som ingår i analysen redovisar vi i anslutning till de respektive resultatdelar där de ingår.

I delar av analysen studerar vi gruppskillnader utifrån olika demografiska och socioekonomiska faktorer. Variablerna som används och deras kodningar är följande: kön (man=0, kvinna=1), ålder ("-29", "30-49", "50-64", "65-"), hushållsinkomst ("låg", "medel" och "hög"), utbildningsnivå ("grundskola", "gymnasium", "yrkesteknisk högskola" och "universitet"), civilstånd ("ogift/singel" och "gift/sammanboende") samt sysselsättning ("lönearbetar/studerar/pensionär", "egenföretagare", "arbetslös").

För att säkerställa att eventuella individskillnader i oro över coronapandemin inte främst är ett uttryck för skillnader i personlighet mellan respondenterna inkluderade vi mått på de fem stora personlighetsdragen, baserat på den så kallade femfaktormodellen (Big Five): neuroticism, extroversion, öppenhet, vänlighet och samvetsgrannhet (se t.ex. McCrae \& Costa 2003). Dessa fem personlighetsdrag mättes genom en svensk version av den validerade skalan Short Big Five Inventory (Lang, John, Lüdtke m.fl. 2011). Studiedeltagarna fick ta ställning till i vilken utsträckning 15 personbeskrivningar passade in på dem själva (till exempel för neuroticism: "oroar mig mycket", "blir lätt nervös", och "är avspänd, hanterar stress väl"). Utifrån respondenternas svar skapade vi sedan additiva index (0-10) för vart och ett av de fem personlighetsdragen.

Vidare använde vi ett antal enkätfrågor som rör graden av tillit till andra människor samt tillit till politiker och institutioner. Utöver frågor om mellanmänsklig och politisk tillit, där vi frågade om respondenternas generella grad av tillit till "andra människor" och "politiker", använde vi oss av frågor som rörde graden av förtroende för en rad institutioner och samhällsaktörers agerande under coronapandemin (Folkhälsomyndigheten, sjukvården, forskare). Vi ställde även tre frågor som rörde respondenternas livsåskådning där vi fokuserade på den självrapporterade graden av religiositet samt på politisk ideologi. Den sistnämnda mättes med två frågor som fångar en ekonomisk (för- 
delningspolitisk) respektive en kulturell (liberal kontra konservativ) politisk-ideologisk dimension (se Carmines \& D’Amico 2015).

Medan tidigare forskning kring coronapandemin inte har gjort skillnad mellan oro och riskuppfattningar (se t.ex. Dryhurst, Schneider, Kerr m.fl. 2020) så gör vi en distinktion mellan de risker man upplever under coronapandemin och oron över pandemin. För att mäta riskuppfattningar använde vi först två enkätfrågor om hur farligt man tror att coronaviruset är. Respondenterna fick här svara på en femgradig Likertskala för att ta ställning till följande påståenden: "Coronaviruset är mycket farligare än en vanlig influensa" samt "Risken att avlida av coronaviruset är så liten att man kan bortse från den". I syfte att fånga skillnader i respondenternas upplevda risk att de själva, deras familj eller vänner kunde drabbas av coronaviruset, använde vi dessutom två enkätfrågor på vilka respondenterna ombads att svara ja eller nej: "Bedömer du att du tillhör en riskgrupp när det gäller coronaviruset?" samt "Har du familjemedlemmar eller nära vänner som du tror tillhör en riskgrupp när det gäller coronaviruset?".

Metoderna som används i denna studie är främst deskriptiva och vi presenterar resultaten i form av frekvenser och procentsatser samt medelvärden och medelvärdesjämförelser. För att studera sambanden mellan oron över coronapandemin och andra faktorer använder vi även korrelationsanalys (Pearsons $r$ ) och regressionsanalys (OLS). Den sistnämnda används främst för att konstanthålla olika förklaringsfaktorer och därmed kunna urskilja varje enskild variabels bidrag när det gäller att förklara människors oro över coronapandemin.

\section{Resultat}

\section{Hur utbredd är oron över coronapandemin?}

I syfte att bättre förstå människors oro över coronapandemin i Sverige inleder vi med en beskrivning av svarsfördelningen på frågan som fångar den övergripande oron över pandemin: "På det hela taget, hur oroad är du över coronapandemin?". Respondenterna svarade på en elvagradig skala där 0 betyder "inte alls oroad" och där 10 betyder "extremt oroad". Resultaten i Figur 1 visar att $63 \%$ av respondenterna har angett ett värde som är högre än skalans mittenalternativ medan $24,5 \%$ har angett ett lägre värde. När vi fokuserar på de högsta värdena finner vi att nästan en tredjedel av respondenterna $(30,7 \%)$ har valt något av värdena 8 till 10 på orosskalan, vilket är en indikation på att en relativt stor grupp i samhället är mycket eller extremt oroade över pandemin. Medelvärdet och medianen är 6,0 respektive 6,5 och standardavvikelsen är 2,5. Om man ser till fördelningen och centralmåtten tycks det alltså finnas en utbredd oro över coronapandemin i den svenska befolkningen. 
Figur 1. Oro över coronapandemin, svarsfördelning (0-10).

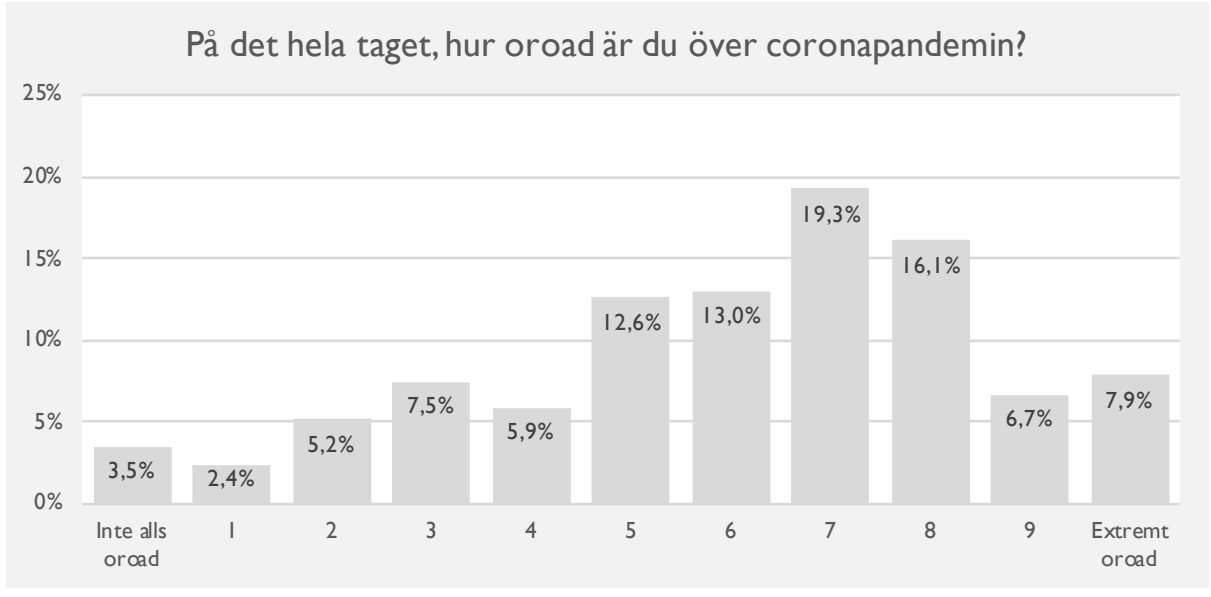

I Figur 2 presenterar vi medelvärdesjämförelser med avseende på oro över coronapandemin uppdelat på kön, ålder, inkomst och civilstånd. Figuren visar att kvinnor, äldre, låginkomsttagare (och medelinkomsttagare) samt de som är gifta eller sammanboende i genomsnitt rapporterar en högre grad av oro. Inte helt oväntat finner vi de största gruppskillnaderna i oro mellan de som är yngre och de som äldre. Även skillnaden mellan män och kvinnor är markant och anmärkningsvärd; trots att män löper en större risk att drabbas allvarligt vid insjuknande i covid-19 uppvisar de en lägre grad av oro.

Figur 2. Medelvärdesjämförelser i oro (0-10) för grupper utifrån kön, ålder, inkomst och civilstånd.

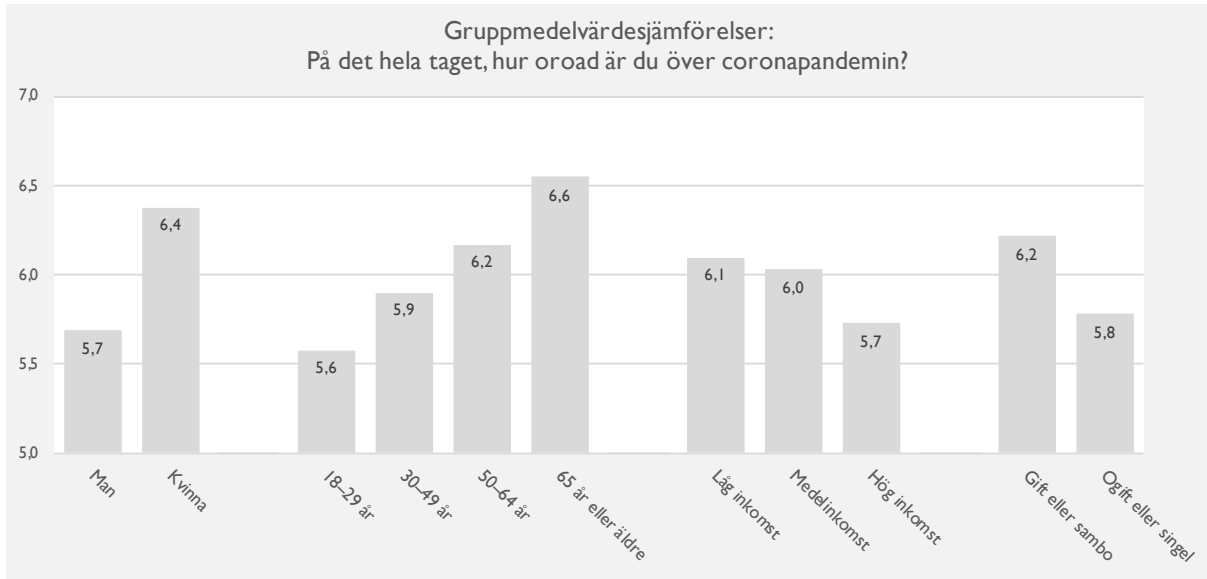

\section{Vad ligger bakom oron över coronapandemin?}

För att öka förståelsen av vad som ligger bakom människors övergripande oro över coronapandemin undersöker vi sambandet mellan den övergripande oron och män- 
niskors mer specifika oro över ett antal av pandemins möjliga negativa konsekvenser. I Figur 3 redovisar vi parvisa korrelationer (Pearsons $r$ ) mellan den övergripande oron och respondenternas oro för specifika konsekvenser. Resultaten visar att oro för att själv smittas av coronaviruset är den specifika oro som är starkast kopplad till den övergripande oron över coronapandemin $(r=0,70)$. Andra källor till oro verkar vara att många människor i Sverige kommer att dö $(r=0,61)$, att anhöriga ska smittas $(r=0,58)$ samt att många människor i världen kommer att dö $(r=0,56)$. Förhållandevis mindre viktiga källor till oro verkar vara sådant som rör ekonomi $(r=0,33-0,37)$ och att inte kunna träffa släkt och vänner $(r=0,37)$. Det framstår alltså som att hotet mot hälsa och liv utgör en särskilt viktig orsak till människors övergripande oro över coronapandemin.

Figur 3. Korrelationer (Pearsons $r$ ) mellan generell oro och oro för specifika konsekvenser.

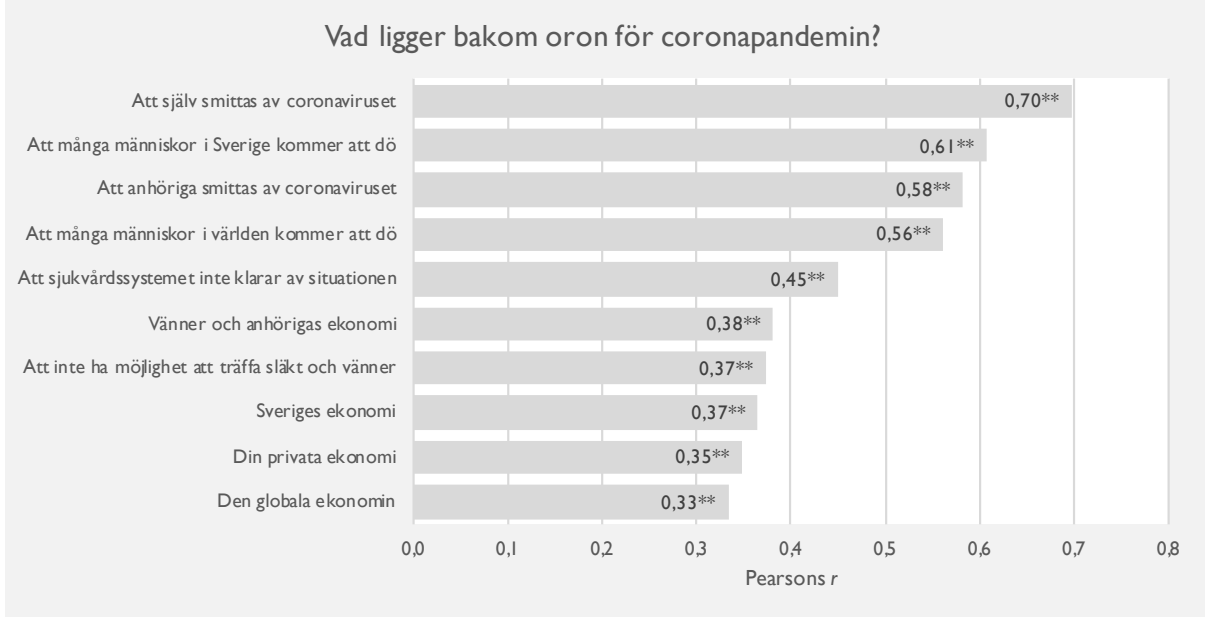

\section{Vad förklarar variation i oron över coronapandemin?}

I nästa steg undersöker vi huruvida en rad faktorer kan förklara variationen i människors oro över coronapandemin. Analysen presenteras i fem regressionsmodeller i Tabell 1, vilka utgår från olika kategorier av förklaringsfaktorer. Då olika demografiska och socioekonomiska faktorer har visat sig påverka den faktiska risken att bli allvarligt sjuk eller avlida i covid-19 börjar vi med att studera hur dessa faktorer är kopplade till människors oro över pandemin i Modell 1. För att säkerställa att eventuella skillnader i oro (till exempel mellan grupper) inte främst har sitt ursprung i personlighetsskillnader inkluderar vi personlighetsdrag i Modell 2. I syfte att undersöka om livsåskådning (religion och politik) samt mellanmänsklig och politisk/institutionell tillit är kopplade till människors oro inkluderar vi stegvis dessa variabler i Modell 3 och 4. Slutligen, för att undersöka betydelsen av riskuppfattningar, samt i vilken mån upplevelser av risk kan förklara eventuella gruppskillnader i oro (till exempel utifrån ålder) så inkluderar vi dessa i Modell 5. 
Tabell 1. Regressionsanalys (OLS) med oro över coronapandemin (0-10) som beroende variabel.

\begin{tabular}{|c|c|c|c|c|c|}
\hline & Modell 1 & Modell 2 & Modell 3 & Modell 4 & Modell 5 \\
\hline & $b$ & $b$ & $b$ & $b$ & $b$ \\
\hline Intercept & $5,25 * * *$ & $2,66 * * *$ & $1,95^{* * *}$ & $1,64 * * *$ & $2,32^{* * *}$ \\
\hline Kön: Kvinna & $0,60^{* * *}$ & $0,29^{* *}$ & $0,32 * *$ & $0,33^{* *}$ & 0,12 \\
\hline \multicolumn{6}{|l|}{ Ålder: } \\
\hline $30-49$ år & 0,22 & $0,28 *$ & $0,32 *$ & $0,28 *$ & 0,00 \\
\hline 50-64 år & $0,53^{* * *}$ & $0,73^{* * *}$ & $0,76^{* * *}$ & $0,70^{* * *}$ & $-0,03$ \\
\hline 65 år eller äldre & $0,85^{* * *}$ & $1,23^{* * *}$ & 1,29 *** & $1,17^{* * *}$ & $-0,17$ \\
\hline \multicolumn{6}{|l|}{ Utbildning: } \\
\hline Grundskola & 0,10 & 0,04 & $-0,03$ & $-0,04$ & $-0,12$ \\
\hline Gymnasium & $-0,07$ & $-0,11$ & $-0,08$ & $-0,09$ & $-0,12$ \\
\hline Yrkesteknisk HS & $-0,06$ & $-0,07$ & $-0,08$ & $-0,04$ & $-0,09$ \\
\hline \multicolumn{6}{|l|}{ Inkomst: } \\
\hline Låg & $0,68^{* * *}$ & $0,44^{* *}$ & $0,35 *$ & $0,37^{*}$ & $0,30 *$ \\
\hline Medel & $0,36^{* *}$ & 0,22 & 0,18 & 0,18 & 0,10 \\
\hline \multicolumn{6}{|l|}{ Sysselsättning: } \\
\hline Egenföretagare & $-0,11$ & $-0,08$ & $-0,16$ & $-0,17$ & $-0,12$ \\
\hline Arbetslös & $-0,23$ & $-0,30$ & $-0,26$ & $-0,27$ & $-0,26$ \\
\hline \multicolumn{6}{|l|}{ Civilstånd: } \\
\hline Ogift eller singel & $-0,65^{* * *}$ & $-0,58^{* * *}$ & $-0,51^{* * *}$ & $-0,51^{* * *}$ & $-0,44 * * *$ \\
\hline \multicolumn{6}{|l|}{ Personlighet: } \\
\hline Neuroticism & & $0,28^{* * *}$ & $0,28^{* * *}$ & $0,27^{* * *}$ & $0,19^{* * *}$ \\
\hline Extroversion & & $0,09^{* * *}$ & $0,08 * *$ & $0,08^{* * *}$ & $0,05 *$ \\
\hline Öppenhet & & 0,02 & 0,02 & 0,01 & 0,04 \\
\hline Vänlighet & & 0,05 & $0,07^{*}$ & 0,05 & 0,00 \\
\hline Samvetsgrannhet & & $0,08^{* *}$ & $0,09^{* *}$ & $0,07^{*}$ & 0,04 \\
\hline Religiositet & & & $0,11^{* * *}$ & $0,11^{* * *}$ & $0,09^{* * *}$ \\
\hline \multicolumn{6}{|l|}{ Politisk ideologi: } \\
\hline Ekonomiskt höger & & & 0,00 & 0,00 & 0,03 \\
\hline Kulturellt konservativ & & & $0,07^{* *}$ & $0,06 *$ & $0,06^{* *}$ \\
\hline \multicolumn{6}{|l|}{ Tillit: } \\
\hline Mellanmänsklig & & & & $-0,05^{*}$ & 0,00 \\
\hline Politiker & & & & $0,07^{* *}$ & $0,07^{* *}$ \\
\hline
\end{tabular}




\begin{tabular}{|c|c|c|c|c|c|}
\hline \multirow[t]{2}{*}{ Forts. tabell 1} & Modell 1 & Modell 2 & Modell 3 & Modell 4 & Modell 5 \\
\hline & $b$ & $b$ & $b$ & $b$ & $b$ \\
\hline \multicolumn{6}{|l|}{ Förtroende (corona): } \\
\hline Regeringen & & & & 0,05 & $0,08^{* *}$ \\
\hline Folkhälsomyndigheten & & & & $-0,18^{* * *}$ & $-0,12^{* * *}$ \\
\hline Sjukvården & & & & $0,08^{* *}$ & $-0,01$ \\
\hline Forskare & & & & $0,13^{* * *}$ & $0,06 *$ \\
\hline Tillhör riskgrupp & & & & & $1,09^{* * *}$ \\
\hline $\begin{array}{l}\text { Familj eller vänner tillhör } \\
\text { riskgrupp }\end{array}$ & & & & & $0,34^{* *}$ \\
\hline $\begin{array}{l}\text { Coronaviruset farligare än } \\
\text { influensan }\end{array}$ & & & & & $0,71^{* * *}$ \\
\hline $\begin{array}{l}\text { Risken liten att avlida av } \\
\text { covid-19 }\end{array}$ & & & & & $-0,47^{* * *}$ \\
\hline $\mathrm{R}^{2}$ & 0,046 & 0,100 & 0,124 & 0,150 & 0,337 \\
\hline $\begin{array}{l}\text { Ökning i R }{ }^{2} \text { (jämfört } \\
\text { med föregående modell) }\end{array}$ & - & 0,054 & 0,024 & 0,026 & 0,187 \\
\hline Justerat $\mathrm{R}^{2}$ & 0,041 & 0,095 & 0,117 & 0,141 & 0,329 \\
\hline
\end{tabular}

Kommentarer: Signifikansnivåer: ${ }^{*}=p<0,05 ;{ }^{* *}=p<0,01 ;{ }^{* * *}=p<0,001$. Referenskategorier för kön=man, ålder=18-29 år, utbildning=universitet/högskola, inkomst=hög, sysselsättning=lönearbetande samt övriga (studenter, pensionärer, hemmafru/hemmaman), civilstånd=gift/sambo.

Resultaten i Modell 1, som inkluderar faktorer baserade på demografi och socioekonomi, visar i likhet med de deskriptiva resultaten i Figur 2 att det finns statistiskt signifikanta skillnader i oro relaterade till kön, ålder, inkomst och civilstånd. Kvinnor, äldre (50-64 år samt 65 år eller äldre) låginkomsttagare och gifta eller sammanboende uppger i högre grad att de oroar sig för coronapandemin än män, unga, höginkomsttagare och ogifta eller singlar gör. Utbildningsnivå och sysselsättning tycks dock inte vara relaterade till människors oro. Framför allt verkar ålder bidra till att förklara människors oro då de som är 65 år eller äldre i genomsnitt uppvisar nästan ett skalsteg högre $(b=0,85)$ värden på orosskalan jämfört med referenskategorin (yngre) och denna åldersskillnad utgör därmed den största gruppskillnaden i modellen. I modellen med demografi och socioekonomi finner vi ett $\mathrm{R}^{2}$-värde på 0,046 vilket betyder att modellen förklarar 4,6\% av individvariationen i oro.

Resultaten i Modell 2, som även inkluderar personlighetsdrag, visar på statistiskt signifikanta samband mellan ett flertal personlighetsdrag och oro för coronapandemin. Den starkaste effekten finner vi som förväntat mellan personlighetsdraget neuroticism och oro $(b=0,28)$, vilket tyder på att människor som vanligtvis brukar oroa sig mycket 
också tenderar att oroa sig över coronapandemin. Även om effekterna är jämförelsevis svaga finner vi också att extroversion $(b=0,09)$ och samvetsgrannhet $(b=0,08)$ är positivt kopplade till oro över pandemin. Personlighetsdragen öppenhet och vänlighet tycks däremot inte påverka människors oro. Vidare ser vi även att könsskillnaderna i oro halveras när personlighetsdrag inkluderas i modellen. En möjlig tolkning av denna reducering är att kvinnor i genomsnitt har högre nivåer av neuroticism än män (Schmitt, Realo, Voracek m.fl. 2008), vilket också är det personlighetsdrag som är starkast kopplat till oro. Även de jämförelsevis större åldersskillnaderna i Modell 2 kan möjligen förklaras av att neuroticism är mindre vanligt förekommande bland äldre personer (Soto, John, Gosling m.fl. 2011) och att vi genom att konstanthålla detta personlighetsdrag ser att åldersskillnaderna i oro över pandemin i själva verket är större. Modellen som även inkluderar personlighetsdrag har ett $\mathrm{R}^{2}$-värde på 0,10 och förklarar därmed ytterligare $5,4 \%$ av individvariationen i oro.

När vi lägger till faktorer kopplade till livsåskådning i Modell 3 finner vi att både religiositet och politisk ideologi, som mäts med elvagradiga skalor (0-10), har statistiskt signifikanta effekter på oron. Med avseende på religiositet visar resultaten att oron är högre bland människor som uppger att de är mer religiösa $(b=0,11)$. Vi finner ingen effekt av självrapporterad placering på den ekonomiska vänster-högerskalan men däremot när det gäller den kulturella skalan (liberal-konservativ) då människor med mer konservativ politisk orientering också är mer benägna att oroa sig över coronapandemin $(b=0,07)$. $\mathbf{R}^{2}$-värdet $(0,12)$ visar att modellen som även innefattar livsåskådning förklarar ytterligare $2,4 \%$ av variationen i oro över coronapandemin.

I Modell 4, som dessutom innehåller måtten på mellanmänsklig och politisk tillit liksom människors förtroende för hur samhällets institutioner har hanterat coronapandemin, finner vi flera statistiskt signifikanta effekter. Mellanmänsklig och politisk tillit har motsatta effekter då människor med högre grad av mellanmänsklig tillit tenderar att vara mindre oroade $(b=-0,05)$ medan de med högre grad av politisk tillit tenderar att vara mer oroade $(b=0,07)$. När det gäller förtroendet för hur olika institutioner har hanterat coronapandemin uppvisar de med högt förtroende för sjukvården och forskare en högre grad av oro medan ett högt förtroende för Folkhälsomyndigheten (Fohm) däremot är förknippat med mindre oro. Förtroendet för regeringens hantering av coronapandemin verkar dock varken vara kopplat till en högre eller lägre grad av oro. Modellen med tillit och förtroende har ett $\mathrm{R}^{2}$-värde på 0,15 och förklarar därmed ytterligare 2,6 \% av variationen i oro över coronapandemin.

Slutligen, när vi lägger till riskuppfattningar finner vi i Modell 5 särskilt starka effekter på den upplevda oron över coronapandemin. En betydande effekt i denna kategori är kopplad till frågan om man tillhör en riskgrupp $(b=1,09)$, där de som uppger att de tillhör en riskgrupp är mer oroade över pandemin än de som uppger att de inte tillhör en riskgrupp. Även de som svarat att de har vänner eller familjemedlemmar som tillhör en riskgrupp uppger att de är mer oroade $(b=0,34)$. Riskuppfattningarna om hur farligt coronaviruset är ger båda betydande effekter på oron då uppfattningen att coronaviruset är farligare än influensan är associerat med en högre grad av oro $(b=0,71)$ medan uppfattningen att risken är liten att avlida om man smittas av coronaviruset 
är kopplat till en lägre grad av oro $(b=-0,47)$. Det är dock viktigt att notera att de två sistnämnda koefficienterna avser frågor som (till skillnad från de binära frågorna om riskgrupper) mäts med en femgradig Likertskala. Detta betyder att de resulterande skillnaderna i oro kan anses särskilt stora, då endast en enhets ökning i den femgradiga skalan om hur farligt viruset är i genomsnitt leder till 0,71 enheters ökning av oron. Den sista modellen med riskuppfattningar har ett $\mathrm{R}^{2}$-värde på totalt 0,34 och förklarar därmed ytterligare $18,7 \%$ av variationen i oro över coronapandemin.

\section{Vilka konsekvenser får oron över coronapandemin?}

I den här delen av analysen undersöker vi först om och i så fall hur oro över coronapandemin påverkar människors vardagsbeteenden under pandemin samt sådana beteenden som har direkt koppling till smittspridning och myndigheternas åtgärder. I undersökningen fick respondenterna ange i vilken utsträckning de försöker undvika att bli smittade samt i vilken utsträckning de följer Folkhälsomyndighetens rekommendationer. Respondenterna fick även svara på om de förändrat sina beteenden sedan början av coronapandemin med avseende på en rad olika aktiviteter som att träffa släkt och vänner, göra restaurangbesök, shoppa, motionera, gå på kulturevenemang och arbeta hemifrån. I Figur 4 presenterar vi först svarsfördelningen för frågorna som rör självrapporterade beteenden. Figuren visar att de allra flesta $(79,8 \%)$ instämmer i påståendet "Jag försöker så långt det går att inte bli smittad själv". Även på frågan om i vilken utsträckning man följer Folkhälsomyndighetens rekommendationer svarar de allra flesta $(81,6 \%)$ att de gör det i stor utsträckning, det vill säga något av de fyra högsta värdena på den elvagradiga skalan.

Beträffande eventuella förändringar av vardagsbeteenden under coronapandemin svarar en majoritet (mellan 63 och $74 \%$ ) av respondenterna att de i mindre utsträckning träffat släktingar och vänner, gått på restaurang, bar eller pub, shoppat eller gått på kulturevenemang. En förhållandevis stor andel (48,8 \%) uppger att de tränat eller motionerat på en oförändrad nivå medan $24,1 \%$ har gjort detta mindre och $18,9 \%$ har tränat eller motionerat mer. Gruppen som svarar att de inte förändrat sitt promenadbeteende är även här relativt stor $(50,8 \%)$, men de som uppger att de promenerat mer under coronapandemin är betydligt större (33,2\%) än de som uppger att de promenerat mindre (13,4\%). Slutligen svarar drygt en fjärdedel $(27,5 \%)$ att de jobbat hemifrån mer under coronapandemin. Det ska dock noteras att nästan hälften av respondenterna uppger att frågan om hemarbete inte är tillämplig, vilket kan bero på att många antingen har ett arbete där hemarbete inte är möjligt eller helt enkelt inte arbetar (till exempel arbetslösa, studenter och pensionärer). 
Figur 4. Svarsfördelning: Förekomsten av olika beteenden under coronapandemin (procent).

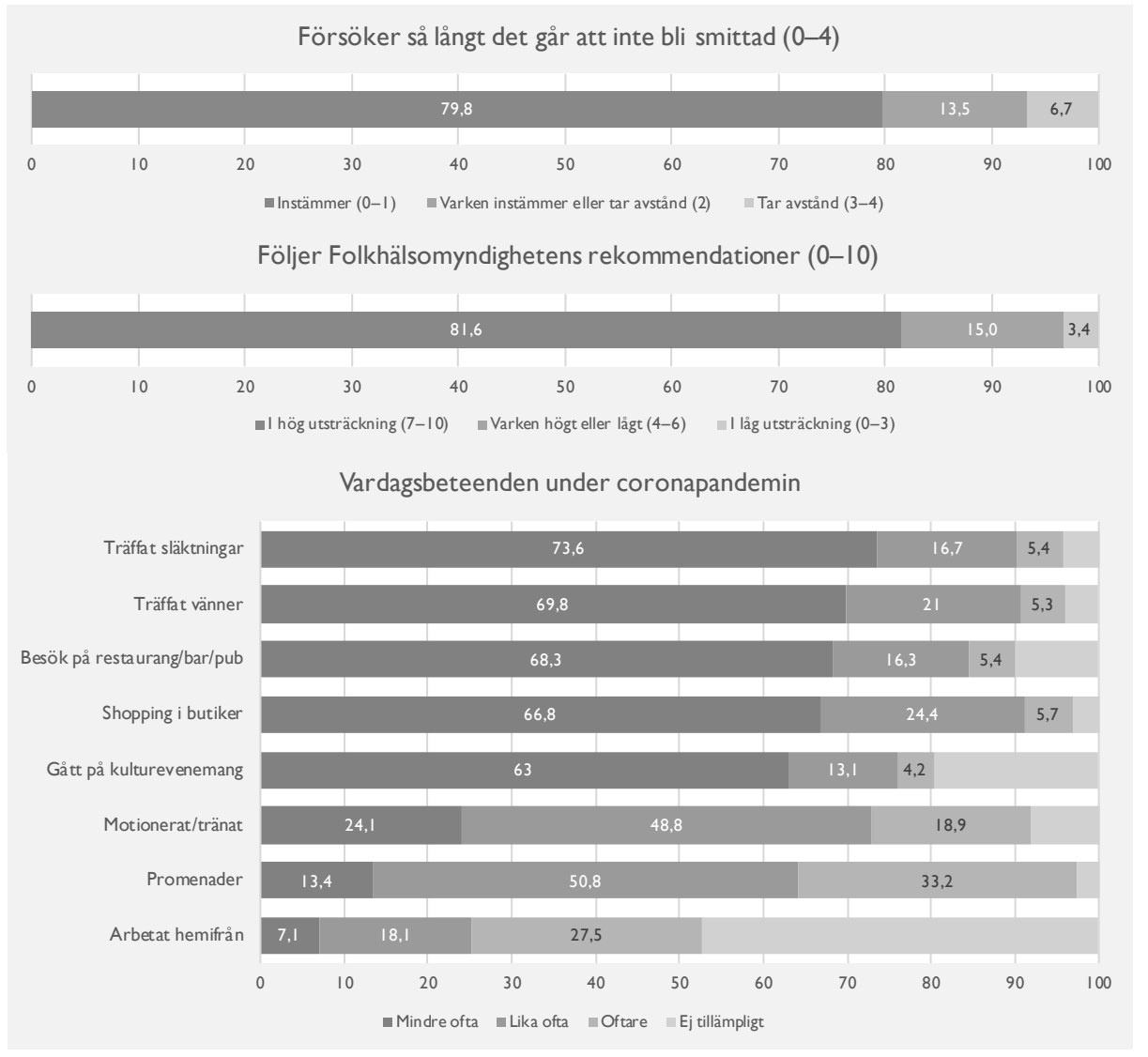

I Figur 5 redovisar vi parvisa korrelationer (Pearsons $r$ ) mellan den övergripande oron över coronapandemin och i vilken utsträckning man ägnat sig åt olika aktiviteter under coronapandemin jämfört med innan pandemin. Resultaten visar att oro över coronapandemin i störst utsträckning kan kopplas till minskningar av fritidsaktiviteter med sociala inslag såsom att träffa vänner $(r=0,25)$, shoppa $(r=0,25)$, besöka bar, pub eller restaurang $(r=0,22)$, träffa släkt $(r=0,20)$ samt att gå på kulturevenemang $(r=0,18)$. Däremot finner vi ett svagare samband mellan oro och minskad fysisk träning $(r=0,10)$. Vidare finns inget samband mellan respondenternas generella oro över coronapandemin och i vilken utsträckning de ägnat mer eller mindre tid åt promenader eller hemarbete. Frånvaron av ett samband mellan oro och promenader skulle kunna förklaras av att denna aktivitet inte ansetts innebära en risk för smittspridning. Det uteblivna sambandet med distansarbete kanske främst kan förklaras av att det snarare är kontextuella faktorer som styr huruvida man har möjlighet att jobba hemifrån eller inte, till exempel vilket yrke man har och vilka rekommendationer som finns på arbetsplatsen. 
Figur 5. Korrelationer (Pearsons $r$ ) mellan oro över coronapandemin och olika beteenden.

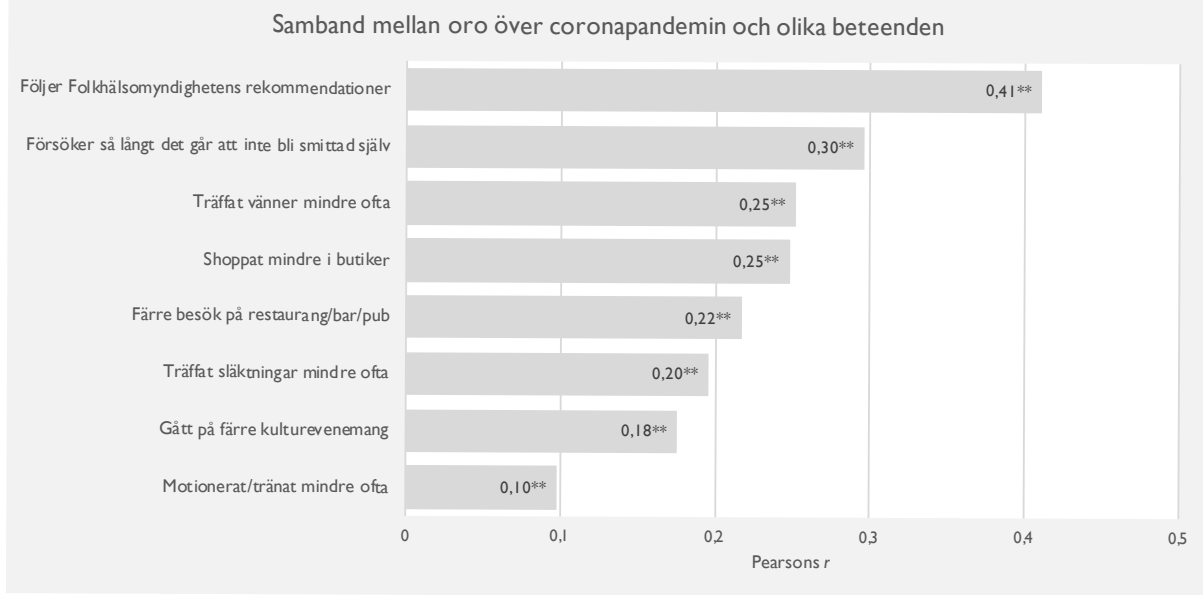

Vi studerar även sambandet mellan generell oro över coronapandemin och åsikter till olika samhällsåtgärder knutna till pandemin. Respondenterna fick instämma i eller ta avstånd från fyra olika påståenden om åtgärder för att minska smittspridningen. Resultaten i Figur 6 visar att oron över coronapandemin generellt samvarierar positivt med en önskan om strängare samhällsåtgärder. Starkast samband mellan oro och attityder finner vi för påståendet som rör strängare åtgärder överlag: "Myndigheterna behöver ta till mer omfattande åtgärder för att minska smittspridningen" ( $r=0,34)$ samt frågan om att reglera isolering $\mathrm{i}$ hemmet hårdare, "Sverige borde ha hårdare regler för att folk ska stanna hemma" $(r=0,33)$. Sambanden går i samma riktning men är något svagare när det gäller åsikter om skolstängningar ("Alla skolor i Sverige borde hållas stängda", $r=0,23$ ) samt ökad testning ("I Sverige borde vi testa fler för coronaviruset", $r=0,21$ ).

Figur 6. Korrelationer (Pearsons $r$ ) mellan oro över coronapandemin och åsikter kring åtgärder för att minska smittspridning.

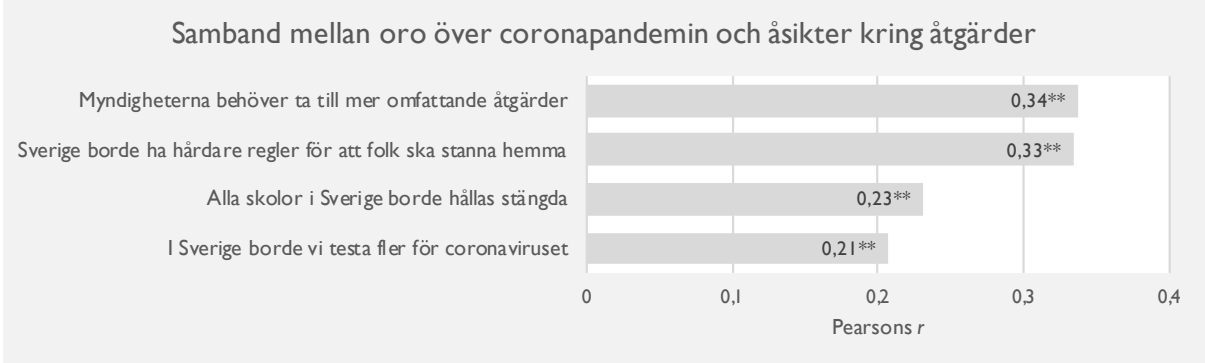


Slutligen, för att undersöka kopplingen mellan generell oro över coronapandemin och människors livskvalitet fick respondenterna uppge hur de tycker att livet påverkats av coronapandemin samt hur nöjda de är med livet i sin helhet. I Figur 7 och 8 presenterar vi svarsfördelningen för de två frågorna. En majoritet av respondenterna tycker att livet har blivit sämre under coronapandemin. Mer specifikt uppger $47 \%$ att livet blivit något sämre och $13 \%$ att livet blivit mycket sämre. När det gäller den övergripande livstillfredsställelsen anger majoriteten av respondenterna värden högre än mittenalternativet på den elvagradiga skalan. Dock är medelvärdet $(6,26)$ markant lägre än medelvärdet för samma fråga i European Social Survey 2018-2019 (7,82). Huruvida denna skillnad primärt beror på en faktisk försämring av svenska folkets livstillfredsställelse i och med coronapandemin, samt i vilken utsträckning metod- eller urvalseffekter spelar in, är dock oklart.

Figur 7. Svarsfördelning: Hur har livet påverkats i och med coronapandemin?

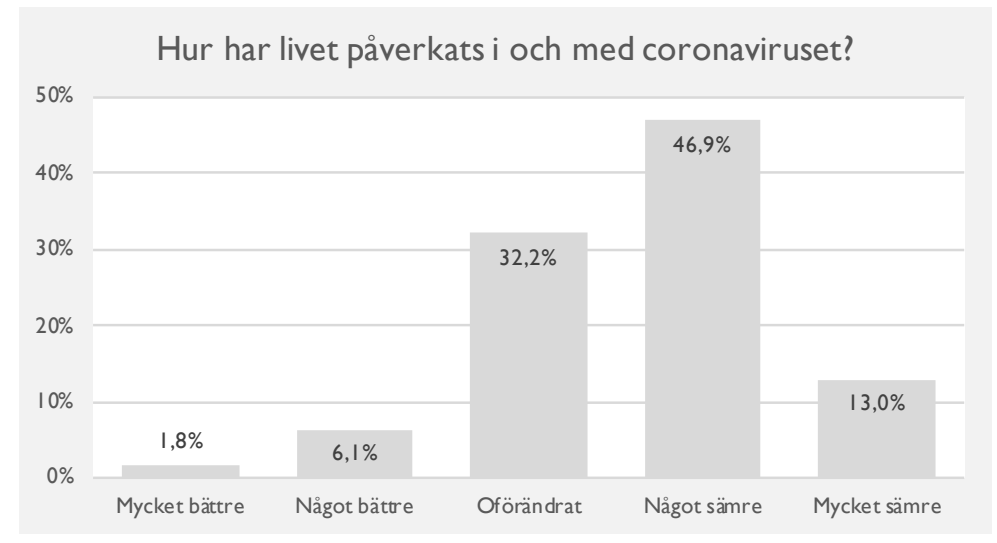

Figur 8. Svarsfördelning: Livstillfredsställelse (0-10).

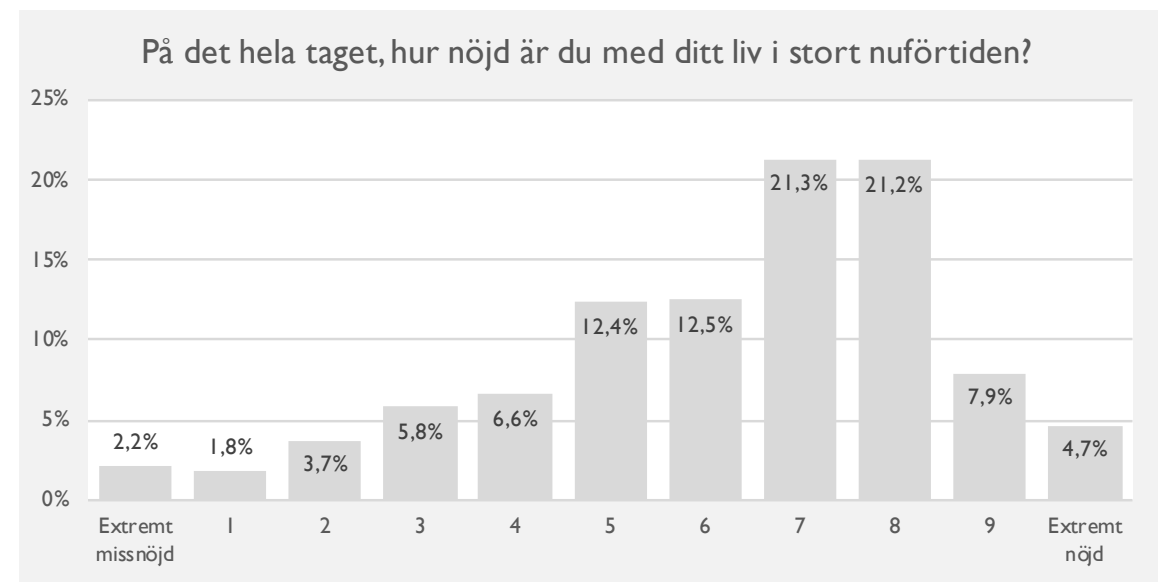


Hur hänger då människors generella oro över coronapandemin ihop med de två olika måtten på livskvalitet? Resultaten i Figur 9 visar att vi inte finner någon statistiskt signifikant korrelation av betydande storlek mellan oro över coronapandemin och generell tillfredsställelse med livet, men däremot ett samband mellan respondenternas oro över coronapandemin och deras bedömning av hur livet påverkats under pandemin (kodad så att höga värden betyder att livet blivit bättre). Detta samband indikerar att människor som är mer oroade också i högre grad upplever att livet under coronapandemin blivit sämre. Men trots detta finner vi alltså inget samband mellan oron över pandemin och den generella livstillfredsställelsen.

Figur 9. Korrelationer (Pearsons $r$ ) mellan oro över coronapandemin och livskvalitet.

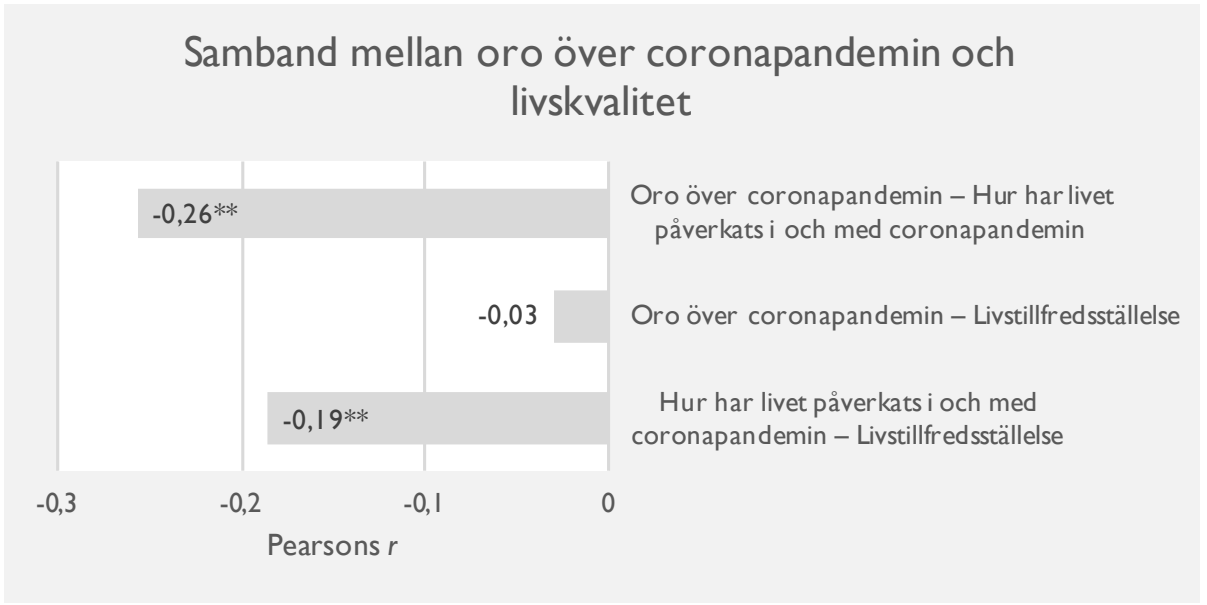

Däremot finner vi ett statistiskt signifikant samband mellan måttet på hur livet påverkats under coronapandemin (här kodad så att höga värden betyder att det blivit sämre) och livstillfredsställelse. Detta resultat föreslår att coronapandemin trots allt haft en negativ inverkan på den generella livstillfredsställelsen, men att denna försämring inte handlar om oron över pandemin.

\section{Diskussion}

I denna artikel har vi undersökt människors oro över coronapandemin i Sverige. Våra resultat visar att oron över coronapandemin är utbredd, där $63 \%$ av respondenterna har angett högre värden än mittenalternativet på skalan som mäter oro. Resultaten visar även att graden av oro skiljer sig åt mellan olika grupper. Framför allt äldre och kvinnor (men även de med lägre inkomster samt de som är gifta eller sambor) uppger att de är mer oroade över pandemin. I likhet med tidigare studier (Barzilay, Moore, Greenberg m.fl. 2020; Kleinberg, van der Vegt \& Mozes 2020) visar våra resultat att 
människor främst oroar sig för att själva bli smittade eller att anhöriga ska smittas av coronaviruset (mikro-oro). Oro över privatekonomin spelar dock en mindre roll även om låginkomsttagare generellt uppvisar en högre grad av oro. Även om oro över konsekvenserna för samhället i stort (makro-oro) spelar en betydelsefull roll - när det gäller oro inför hur många som kommer att avlida i Sverige och i världen - så verkar till exempel oro över samhällsekonomin inte utgöra en lika viktig orsak till människors generella oro över pandemin.

Resultaten visar också att det framför allt är människor som bedömer att de (eller deras nära och kära) tillhör en riskgrupp, eller de som bedömer att viruset $i$ allmänhet utgör en fara, som upplever mer oro. Dessa riskuppfattningar visar sig i stor utsträckning förklara de demografiska skillnaderna i oro, särskilt åldersskillnaderna men även stora delar av skillnaderna mellan män och kvinnor. När det gäller potentiella konsekvenser av människors oro visar resultaten att de som i större utsträckning uppger att de oroar sig även har minskat sina sociala aktiviteter, såsom att träffa släkt och vänner. De som oroar sig mer uppger också att de i större utsträckning följer myndigheternas rekommendationer samt försöker undvika att själva bli smittade. Vidare är de med högre grad av oro även mer benägna att stödja hårdare åtgärder för att minska smittspridningen. De som oroar sig mer upplever också i större utsträckning att deras liv har blivit sämre i och med coronapandemin, jämfört med de som inte oroar sig lika mycket.

Ett centralt resultat av undersökningen är att äldre uppvisar en betydligt högre grad av oro över coronapandemin än yngre åldersgrupper, vilket inte är förvånande med tanke på att risken att bli svårt sjuk eller avlida i covid-19 är större för personer med hög ålder. Även om tidigare forskning visat att äldre generellt upplever mindre oro i vardagen än yngre så tycks detta inte vara fallet för oro över coronapandemin. Detta betyder alltså att många äldre, utöver de som drabbats av de direkta negativa hälsoeffekterna av att insjukna i covid-19, upplever en förhållandevis hög grad av oro. Om man dessutom ser till tidigare forskning om orons effekter på hälsan skulle oron över pandemin därmed kunna ha ytterligare negativa hälsoeffekter i denna grupp. Då våra resultat dessutom visar att de som oroar sig mer också upplever att deras liv blivit sämre under pandemin så framstår det sammantaget som att äldre är en grupp som drabbats särskilt hårt, inte bara i termer av deras överrepresentation i statistiken över svårt sjuka och avlidna i covid-19.

Givet att våra analyser tyder på att människor är mer oroliga över hälsan än över ekonomin i relation till coronapandemin är det inte förvånande att olika mått på socioekonomisk status uppvisar svaga samband med den övergripande oron över pandemin. Till exempel finner vi inga samband mellan utbildning eller arbetslöshet och oro. Dessa resultat är anmärkningsvärda, inte minst då den svenska ekonomin (särskilt vissa branscher) har drabbats relativt hårt. Däremot finner vi att individer med lägre (låg-och medel-) inkomster upplever något mer oro jämfört med individer som har högre inkomster. Det är dock oklart vad som förklarar dessa (relativt små) skillnader i oro mellan olika inkomstgrupper. Då vår data inte innehåller detaljerad information om respondenternas yrke eller deras sysselsättning innan pandemin så vore det fruktbart om framtida forskning undersöker oro över pandemin i olika 
branscher och yrkesgrupper samt bland de som blivit arbetslösa som en direkt följd av pandemin.

När det gäller sambanden mellan personlighetsdrag och oro över coronapandemin visar analyserna att personlighetsdraget neuroticism är starkast kopplat till oro. Detta resultat är väntat eftersom neuroticism till stor del består i att man ofta upplever oro och stress i vardagen. När vi tar hänsyn till neuroticism och andra personlighetsdrag minskar som förväntat (utifrån vad tidigare forskning säger) könsskillnaderna i oro samtidigt som åldersskillnaderna i oro ökar. Detta betyder att framför allt äldre är betydligt mer oroade över pandemin jämfört med yngre grupper trots den generella tendensen bland äldre att oroa sig mindre i allmänhet. Vidare finner vi också att extroversion samvarierar positivt med oro över coronapandemin trots att detta drag förknippats med mindre generell oro i tidigare studier (Gladstone, Parker, Mitchell m.fl. 2005). En förklaring till detta samband kan vara att extroverta individer har ett mer aktivt socialt liv jämfört med introverta individer och därför inser att de löper en större risk att smittas av coronaviruset.

Ett antal andra resultat är värda att diskutera. Till exempel visar analysen att singlar oroar sig mindre för coronapandemin än gifta, vilket förmodligen förklaras av att individer som har en parrelation inte bara oroar sig för egen del utan även för partnern. Dessutom kan risken att smittas vara högre i flerpersonshushåll, vilket kan förklara en högre grad av oro bland gifta eller sambor. Med avseende på livsåskådning finner vi att religiösa individer samt de som identifierar sig som politiskt konservativa upplever en större oro. Kopplingen mellan religiositet och oro är något förvånande då tidigare studier visat att religiositet kan utgöra en buffert mot svåra livsvillkor (Hastings \& Roeser 2020) och därmed kunde förväntas minska oron över pandemin. Vidare, beträffande den högre graden av oro bland politiskt konservativa individer är resultaten möjligen inte lika förvånande då de konservativa högerpartierna i Sverige, till skillnad från i USA (Calvillo, Ross, Garcia m.fl. 2020), var i opposition vid undersökningstillfället. I och med att regeringsmakten och därmed möjligheterna att utforma åtgärderna för att hantera pandemin ligger hos de politiska motståndarna kan man tänka sig att högersympatier är förknippade med en högre grad av oro över pandemin i Sverige. Samtidigt finner vi endast en koppling mellan den kulturella politiska dimensionen (liberal-konservativ) och oro. Men då en stor samhällsomvandling, såsom en global pandemi och de påföljande samhälleliga åtgärderna, förmodligen utgör ett särskilt hot just för individer med en kulturellt konservativ livsåskådning är det kanske inte förvånande att den kulturella dimensionen tycks vara betydelsefull.

Ett annat anmärkningsvärt resultat rör förtroendet för myndigheternas agerande under pandemin, då det framkommer att ett större förtroende för forskare och sjukvården är kopplat till en högre grad av oro samtidigt som ett större förtroende för Folkhälsomyndigheten är kopplat till en lägre grad av oro. Även om vi föredrar att inte spekulera kring orsakerna till dessa resultat kan vi ändå konstatera att det är ett intressant resultat att förtroendet för dessa aktörer (forskare och sjukvården kontra Folkhälsomyndigheten) är relaterat till människors oro över coronapandemin i motsatt riktning.

Vidare finner vi inte något samband mellan oro för coronapandemin och den allmän- 
na livstillfredsställelsen. Däremot anser de som oroar sig för coronapandemin att livet har blivit sämre i och med pandemin. En möjlig tolkning av dessa till synes motstridiga resultat är att människor upplever att hotet från coronapandemin visserligen gjort livet sämre men att de samtidigt uppfattar att situationen är tillfällig och därmed inte påverkar den övergripande bedömningen av livet. Frågan är dock vad som händer med människors livstillfredsställelse om coronapandemin fortgår under ännu längre tid. Detta är en viktig fråga för framtida forskning om de potentiella konsekvenserna av coronapandemin.

När det gäller sociala aktiviteter och i vilken utsträckning man följer myndigheternas rekommendationer ligger resultaten i denna studie i linje med tidigare forskning som har visat att oro kan ha både positiva och negativa konsekvenser. Även om oron över coronapandemin har inneburit inskränkningar i människors vardagsliv och därmed har negativa konsekvenser för sådant som de flesta värdesätter verkar oron också ha positiva konsekvenser för både individen och för samhället eftersom den verkar leda till en minskad benägenhet att utsätta sig själv eller andra för smittorisker. Vidare är de som är mer oroade också mer benägna att tycka att de samhälleliga åtgärderna borde vara mer omfattande, vilket skulle kunna ses som en positiv konsekvens i den utsträckning sådana åtgärder räddar liv och hälsa.

Det är dock värt att understryka att oro - i detta fall över coronapandemin - bör ses som något betydelsefullt och viktigt i sig oavsett dess konsekvenser. De flesta skulle nog hålla med om att mindre oro, allt annat lika, är att föredra framför mer oro. Våra resultat visar att oron över pandemin är utbredd i det svenska samhället. Dessutom sätter resultaten frågor om ojämlikhet och rättvisa i förgrunden, då oron över pandemin (utöver rent hälsomässiga eller ekonomiska konsekvenser) är ojämnt fördelad i samhället (jfr Graham 2020). Detta gäller inte minst för äldre som utöver att vara en särskilt utsatt grupp när det gäller risken att bli allvarligt sjuk eller avlida till följd av covid-19 även upplever en jämförelsevis hög grad av oro över coronapandemin.

Vi vill slutligen understryka att denna studie är genomförd vid en viss tidpunkt (i juni 2020) och att mycket har hänt efter att vår datainsamling genomfördes. Framför allt har vi under hösten och vintern upplevt en andra våg av coronapandemin i Sverige som följts av striktare åtgärder än under den första vågen. Mot bakgrund av detta är det viktigt att framtida forskning följer upp och studerar coronapandemins konsekvenser för människors oro över en längre tidsperiod. Vidare vill vi även betona att denna studie är begränsad till en svensk kontext och att även om forskning på orosliknande fenomen visar på förhöjda nivåer i många länder vet vi inte om våra resultat är generaliserbara utanför Sverige. En viktig förtjänst med denna studie är att vi till skillnad från till exempel Dryhurst med flera (2020) gör en distinktion mellan oro och riskuppfattningar. Detta gör att vi kan uttala oss om, samt påvisa vikten av att studera, hur människors subjektiva upplevelser av risker knutna till coronapandemin är centrala för att förstå den utbredda oron, inte minst bland äldre (men även andra grupper) som redan drabbats förhållandevis hårt av coronavirusets hälsomässiga konsekvenser.

Vi är även ödmjuka inför det faktum att en stor komplexitet gömmer sig bakom våra resultat och att denna typ av enkätstudie har sina begränsningar vad gäller möjligheterna att förstå enskilda individers upplevelser av oro under coronapandemin. Här 
vill vi understryka vikten av andra sociologiska perspektiv och angreppssätt som kan komplettera den översiktliga ansatsen i denna studie, till exempel genom att på ett mer djupgående sätt belysa människors upplevelser av oro under coronapandemin. Det är dock vår förhoppning att denna studie bidragit med nya insikter kring människors oro över coronapandemin i Sverige - inte minst när det gäller hur utbredd oron är, vad den består i, hur den skiljer sig mellan individer och grupper samt vilka konsekvenser den får.

\section{Referenser}

Barzilay, R., T.M. Moore, D.M. Greenberg, G.E. DiDomenico, L.A. Brown, L.K. White, R.C Gur \& R.E. Gur (2020) "Resilience, COVID-19-related stress, anxiety and depression during the pandemic in a large population enriched for healthcare providers", Translational Psychiatry 10 (291):1-8. https://doi.org/10.1038/s41398020-00982-4

Basevitz, P., D. Pushkar, J. Chaikelson, M. Conway \& C. Dalton (2008). ”Age-related differences in worry and related processes", The International Journal of Aging and Human Development 66 (4):283-305. https://doi.org/10.2190\%2FAG.66.4.b

Boehnke, K., S. Schwartz, C. Stromberg \& L. Sagiv (1998) "The structure and dynamics of worry. Theory, measurement, and cross-national replications", Journal of Personality 66 (5):745-782. https://doi.org/10.1111/1467-6494.00031

Borkovec, T.D. (1994) "The nature, functions, and origins of worry", 5-33 i G.C.L. Davey \& F. Tallis (red.) Worrying. Perspectives on theory, assessment and treatment. Oxford: John Wiley \& Sons.

Brodeur, A., D.M Gray, A. Islam \& S. Bhuiyan (2020) "A Literature Review of the Economics of Covid-19", IZA Discussion Paper No. 13411, https://ssrn.com/abstract $=3636640$

Brosschot, J.F., W. Gerin \& J.F. Thayer (2006) "The perseverative cognition hypothesis. A review of worry, prolonged stress-related physiological activation, and health", Journal of Psychosomatic Research 60 (2):113-124. https://doi.org/10.1016/j. jpsychores.2005.06.074

Brück, T., N. Ferguson, P. Justino \& W. Stojetz (2020) "Trust in the time of Corona", IZA Discussion Paper No. 13386, https://ssrn.com/abstract=3631597

Bäuerle, A., M. Teufel, V. Musche, B. Weismüller, H. Kohler, M. Hetkamp, N. Dörrie, A. Schweda \& E-M. Skoda (2020) "Increased generalized anxiety, depression and distress duringthe COVID-19 pandemic. A cross-sectional study in Germany", Journal of Public Health 42 (4):672-678. https://doi.org/10.1093/pubmed/fdaa106

Calvillo, D.P., B.J. Ross, R.J. Garcia, T.J. Smelter \& A.M. Rutchick (2020) "Political ideology predicts perceptions of the threat of covid-19 (and susceptibility to fake news about it)", Social Psychological and Personality Science 11 (8):1119-1128. https:// doi.org/10.1177/1948550620940539

Carmines, E.G. \& N.J. D’Amico (2015) "The new look in political ideology research", Annual Review of Political Science 18 (1):205-216. https://doi.org/10.1146/ annurev-polisci-060314-115422 
Chapman, G.B. \& E.J. Coups (2006) "Emotions and preventive health behavior. Worry, regret, and influenza vaccination”, Health Psychology 25 (1):82-90. https:// doi.org/10.1037/0278-6133.25.1.82

Davey, G. (1994) "Pathological worrying as exacerbated problem-solving", 35-59 i G. Davey \& F. Tallis (red.) Worrying. Perspectives on theory, assessment and treatment. New York: John Wiley \& Sons.

Douglas, M. (1966) Purity and danger. An analysis of concepts of pollution and taboo. New York: Praeger.

Douglas, M. \& A. Wildavsky (1982) Risk and culture. Berkeley: University of California Press.

Dryhurst, S., C.R. Schneider, J. Kerr, A.L.J. Freeman, G. Recchia, A.M. van der Bles, D. Spiegelhalter \& S. van der Linden (2020) "Risk perceptions of COVID-19 around the world", Journal of Risk Research 23 (7-8):994-1006. https://doi.org/10. 1080/13669877.2020.1758193

Ekonomifakta (2020) "Varsel om uppsägning”, https://www.ekonomifakta.se/Fakta/ Arbetsmarknad/Arbetsloshet/Varsel/ (hämtningsdatum 7 januari 2021).

Fohm (2021) "Folkhälsomyndigheten. Antal fall av covid-19 i Sverige", https://experience.arcgis.com/experience/09f821667ce64bf7be6f9f87457ed9aa/page/page_0/ (hämtningsdatum 26 januari 2021).

Fors, F. \& B. Brülde (2011) "Välbefinnande och livstillfredsställelse i dagens Sverige", 339-363 i S. Holmberg, L. Weibull \& H. Oscarsson (red.) Lycksalighetens ö. Fyrtioen kapitel om politik, medier och samhälle. Göteborg: SOM-institutet, Göteborgs universitet.

Fresco, D.M., R.G Heimberg, D.S. Mennin \& C.L. Turk (2002) "Confirmatory factor analysis of the Penn State Worry Questionnaire", Behaviour Research and Therapy 40 (3):313-323. https://doi.org/10.1016/S0005-7967(00)00113-3

Freeston, M.H., J. Rhéaume, H. Letarte, M.J. Dugas \& R. Ladouceur (1994) "Why do people worry?", Personality and Individual Differences 17 (6):791-802. https:// doi.org/10.1016/0191-8869(94)90048-5

Gladstone, G.L., G.B. Parker, P.B. Mitchell, G.S. Malhi, K.A. Wilhelm \& M.-P. Austin (2005) "A brief measure of worry severity (BMWS). Personality and clinical correlates of severe worriers", Journal of Anxiety Disorders 19 (8):877-892. https:// doi.org/10.1016/j.janxdis.2004.11.003

Graham, H. (2020) "Hysteresis and the sociological perspective in a time of crisis", Acta Sociologica 63 (4):450-452. https://doi.org/10.1177/0001699320961814

Gustavsson, J. \& L. Beckman (2020) "Compliance to recommendations and mental health consequences among elderly in Sweden during the initial phase of the COVID-19 pandemic. A cross sectional online survey", International Journal of Environmental Research and Public Health 17 (15):5380. https://doi.org/10.3390/ ijerph17155380

Hacker, J.S., P. Rehm \& M. Schlesinger (2013) "The insecure American. Economic experiences, financial worries, and policy attitudes", Perspectives on Politics 1 (1):23-49. https://www.jstor.org/stable/43280688

Hastings, O.P. \& K.K. Roeser (2020) "Happiness in hard times. Does religion buffer 
the negative effect of unemployment on happiness?”, Social Forces 99 (2):447-473. https://doi.org/10.1093/sf/soaa018

Huang, Y. \& N. Zhao (2020) "Generalized anxiety disorder, depressive symptoms and sleep quality during COVID-19 outbreak in China. A web-based crosssectional survey", Psychiatry Research 288:112954. https://doi.org/10.1016/j. psychres.2020.112954

Jordan, R.E., P. Adab \& K.K. Cheng (2020) "Covid-19. Risk factors for severe disease and death", BMJ 368:m1198. https://doi.org/10.1136/bmj.m1198

Jovančević, A. \& N. Milićević (2020) "Optimism-pessimism, conspiracy theories and general trust as factors contributing to COVID-19 related behavior. A cross-cultural study", Personality and Individual Differences 167:110216. https://doi.org/10.1016/j. paid.2020.110216

Kahan, D.M., D. Braman, J. Gastil, P. Slovic \& C.K. Mertz (2007) "Culture and identity-protective cognition. Explaining the white-male effect in risk perception", Journal of Empirical Legal Studies 4 (3):465-505. https://doi.org/10.1111/ j.1740-1461.2007.00097.x

Kertz, S.J., J.S. Bigda-Peyton, D.H. Rosmarin \& T. Björgvinsson (2012) ”The importance of worry across diagnostic presentations. Prevalence, severity and associated symptoms in a partial hospital setting", Journal of Anxiety Disorders 26 (1):126-133. https://doi.org/10.1016/j.janxdis.2011.10.005

Kivi, M., I. Hansson \& P. Bjälkebring (2020) "Up and about. Older adults' well-being during the COVID-19 pandemic in a Swedish longitudinal study", The Journals of Gerontology: Series B 76 (2):e4-e9. https://doi.org/10.1093/geronb/gbaa084

Kleinberg, B., I. van der Vegt \& M. Mozes (2020) "Measuring emotions in the COVID-19 Real World Worry Dataset", arXiv.org. https://arxiv.org/abs/2004.04225

Lang, F.R., D. John, O. Lüdtke, J. Schupp \& G.G. Wagner (2011) "Short assessment of the Big Five. Robust across survey methods except telephone interviewing", Behavior Research Methods 43 (2):548-567. https://doi.org/10.3758/s13428-011-0066-z

Mann, F.D., R.F. Krueger \& K.D. Vohs (2020) "Personal economic anxiety in response to COVID-19", Personality and Individual Differences 167:110233. https:// doi.org/10.1016/j.paid.2020.110233

McCrae, R.R. \& P.T. Costa Jr (2003) Personality in adulthood. A five-factor theory perspective. New York: Guilford Press.

Moser, R.P., K. Mccaul, E. Peters, W. Nelson \& S.E. Marcus (2007) ”Associations of perceived risk and worry with cancer health-protective actions. Data from the Health Information National Trends Survey (HINTS)", Journal of Health Psychology 12 (1):53-65. https://doi.org/10.1177/1359105307071735

Ng, W., E. Diener, R. Aurora \& J. Harter (2009) "Affluence, feelings of stress, and well-being", Social Indicators Research 94 (2):257-271. https://doi.org/10.1007/ s11205-008-9422-5

Paolini, L., A.P. Yanez \& W.E. Kelly (2006) "An examination of worry and life satisfaction among college students", Individual Differences Research 4 (5):331-339.

Patel, J.A., F.B.H. Nielsen, A.A. Badiani, S. Assi, V.A. Unadkat, B. Patel, R. Ravin- 
drane \& H. Wardle (2020) "Poverty, inequality and COVID-19. The forgotten vulnerable", Public Health 183:110-111. https://doi.org/10.1016/j.puhe.2020.05.006

Roy, D., S. Tripathy, S. Kumar Kar, N. Sharma, S. Kumar Verma \& V. Kaushal (2020) "Study of knowledge, attitude, anxiety \& perceived mental healthcare need in Indian population during COVID-19 pandemic", Asian Journal of Psychiatry 51 (102083). https://doi.org/10.1016/j.ajp.2020.102083

Sabat, I., S. Neuman-Böhme, N.E. Varghese, P.P. Barros, W. Brouwer, J. van Exel, J. Schreyögg \& T. Stargardt (2020) "United but divided. Policy responses and people's perceptions in the EU during the COVID-19 outbreak", Health Policy 124 (9):909-918. https://doi.org/10.1016/j.healthpol.2020.06.009

Salari, N., A. Hosseinian-Far, R. Jalali, A. Vaisi-Raygani, S. Rasoulpoor, M. Mohammadi, S. Rasoulpoor \& B. Khaledi-Paveh (2020) "Prevalence of stress, anxiety, depression among the general population during the COVID-19 pandemic. A systematic review and meta-analysis", Globalization and Health 16 (57). https://doi. org/10.1186/s12992-020-00589-w

SCB (2020). "Statistiska centralbyrån. Historiskt stor BNP-nedgång andra kvartalet", https://scb.se/hitta-statistik/statistik-efter-amne/nationalrakenskaper/nationalrakenskaper/nationalrakenskaper-kvartals-och-arsberakningar/pong/statistiknyhet/ nationalrakenskaper-2a-kvartalet-20202/ (hämtningsdatum 7 januari 2021).

Schmitt, D.P., A. Realo, M. Voracek, M. \& J. Allik (2008) "Why can't a man be more like a woman? Sex differences in Big Five personality traits across 55 cultures", Journal of Personality and Social Psychology 94 (1):168-182. https://doi. org/10.1037/0022-3514.94.1.168

Schroder, H.S., D.A. Clark \& J.S. Moser (2019) "Screening for problematic worry in adults with a single item from the Penn State Worry Questionnaire", Assessment 26 (2):336-346. https://doi.org/10.1177/1073191117694453

Sjöberg, L. (1998) "Worry and risk perception", Risk Analysis 18 (1):85-93. https://doi. org/10.1111/j.1539-6924.1998.tb00918.x

Shiloh, S., C.H. Wade, J.S. Roberts, S.H. Alford \& B.B. Biesecker (2013) "Associations between risk perceptions and worry about common diseases. A between- and within-subjects examination", Psychology \& Health 28 (4):434-449. https://doi.org /10.1080/08870446.2012.737464

Solomou, I. \& F. Constantinidou (2020) "Prevalence and predictors of anxiety and depression symptoms during the COVID-19 pandemic and compliance with precautionary measures: Age and sex matter", International Journal of Environmental Research and Public Health 17 (14):4924. https://doi.org/10.3390/ijerph17144924

Soto, C.J., O.P. John, S.D. Gosling \& J. Potter (2011) "Age differences in personality traits from 10 to 65. Big Five domains and facets in a large cross-sectional sample", Journal of Personality and Social Psychology 100 (2):330-348. https://doi. org/10.1037/a0021717

Sweeny, K. \& M.D. Dooley (2017) "The surprising upsides of worry", Social and Personality Psychology Compass 11 (4):e12311. https://doi.org/10.1111/spc3.12311 van der Vegt, I. \& B. Kleinberg (2020) "Women worry about family, men about the 
economy. Gender differences in emotional responses to COVID-19” i S. Aref, K. Bontcheva, M. Braghieri, F. Dignum, F. Giannotti, F. Grisolia \& D. Pedreschi (red.) Social Informatics. SocInfo 2020. Lecture Notes in Computer Science 12467. Cham: Springer. https://doi.org/10.1007/978-3-030-60975-7_29

Watkins, E.R. (2008) "Constructive and unconstructive repetitive thought", Psychological Bulletin 134 (2):163-206. https://doi.org/10.1037/0033-2909.134.2.163

Williamson, E.J., A.J. Walker, K. Bhaskaran, S. Bacon, C. Bates, C.E. Morton, H.J. Curtis, A. Mehrkar, D. Evans, P. Inglesby, J. Cockburn, H.I. McDonald, B. MacKenna, L. Tomlinson, I.J. Douglas, C.T. Rentsch, R. Mathur, A.Y.S. Wong, R. Grieve, D. Harrison, H. Forbes, A. Schultze, R. Croker, J. Parry, F. Hester, S. Harper, R. Perera, S.J.W. Evans, L. Smeeth \& B. Goldacre (2020) "Factors associated with COVID-19-related death using OpenSAFELY", Nature 584 (7821):430-436. https://doi.org/10.1038/s41586-020-2521-4

Wilkinson, I. (2001) "Social theories of risk perception. At once indispensable and insufficient", Current Sociology 49 (1):1-22. https://doi.org/10.1177/0011392101049001002

\title{
Författarpresentation
}

Joakim Kulin är doktor i sociologi och forskare på Sociologiska institutionen vid Umeå universitet. Hans forskningsintressen återfinns främst inom politisk sociologi där han fokuserar på attityder och beteenden kopplade till teman som välfärdsstat, invandring och klimatförändringar.

Ingemar Johansson Sevä är docent i sociologi och universitetslektor vid Sociologiska institutionen, Umeå universitet. Hans forskningsintressen handlar främst om politisk sociologi med fokus på attityder och beteenden i relation till välfärdsstat, miljö och klimatförändringarna. Övriga forskningsintressen innefattar småföretagande och subjektivt välbefinnande.

Mikael Hjerm är professor vid Sociologiska institutionen, Umeå universitet. Han forskar huvudsakligen om främlingsfientlighet och närliggande attityder. Han är också forskningsledare för Comparative Research Center Sweden.

Filip Fors Connolly är doktor i sociologi och forskningssamordnare vid Sociologiska institutionen, Umeå universitet. Hans forskning rör livskvalitet och i synnerhet subjektivt välbefinnande, som syftar till att beskriva och förklara skillnader i välbefinnande såväl på individnivå som på gruppnivå.

\author{
Kontaktuppgifter \\ Joakim Kulin \\ Sociologiska institutionen \\ Umeå universitet \\ Mediegränd 14, Norra Beteendevetarhuset, 90187 Umeå \\ joakim.kulin@umu.se
}

